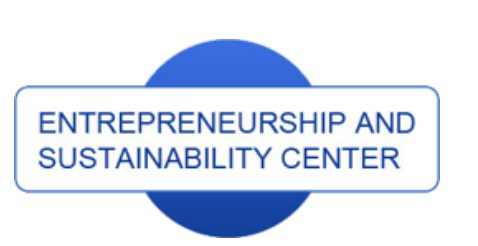

Publisher

enterprise

europe

network

Business Support on Your Doorstep

http://jssidoi.org/esc/home

\title{
Clarivate
Analytics \\ NEW APPROACH TO DETERMINING THE ECONOMIC POTENTIAL OF RURAL AREA ON THE EXAMPLE OF THE SOUTH BOHEMIAN REGION OF THE CZECH REPUBLIC*
}

\section{Petra Pártlová ${ }^{1}$, Zuzana Dvoř́áková Líšková ${ }^{2}$, Miroslav Felcan ${ }^{3}$, Jarmila Straková ${ }^{4}$, Jan Váchal ${ }^{5}$, Jozef Polomský 6}
1,4,5,6 Institute of Technology and Business in České Budějovice, Faculty of Corporate Strategy, Department of Management, Okružni 517/10,370 01 ČeskéBudějovice, Czech Republic
${ }^{2}$ University of South Bohemia, Faculty of Economics, Department of Regional Management České Budějovice, Branišovská 1645/31a, České Budějovice, 370 05, Czech Republic
${ }^{3}$ Academy of the Police Force in Bratislava, Sklabinská 1, 83517 Bratislava 35, Slovak Republic

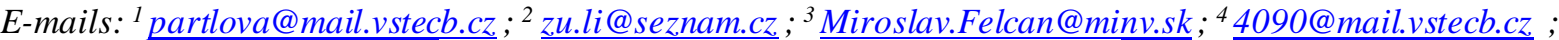
5 $\underline{4027 @ \text { mail.vstecb.cz }} ;{ }^{6}$ 24574@mail.vstecb.cz
\end{abstract}

Received 18 May 2020; accepted 25 September 2020; published 30 December 2020

\begin{abstract}
The paper discusses a new approach to determining the economic potential of rural area on the example of the region of South Bohemia in the Czech Republic. The approach is based on a comprehensive economic model, consisting of four sub-models (SM). Such aggregate model is used as the basis for the analysis of regional economic potential. The SMs were defined by the Progressivity Index of the Economic Structure, Trend of the Economic Structure Index, Business Activity Rate and Recreation and Tourism Index. The mathematical-statistical method of Stepwise backward analysis was used as an analytical tool. During this stage, the data database from Ekotoxa was used. Practically, the first two SMs named were verified. Furthermore, the implementation of the results was designed and tested by the researchers. Two research objectives were fulfilled, namely the construction of summary and partial models, and the
\end{abstract}

* This research was funded by Technology Agency of the Czech Republic, programme of ETA, project reg. no. TL01000349Stabilization and development of SME in rural areas.
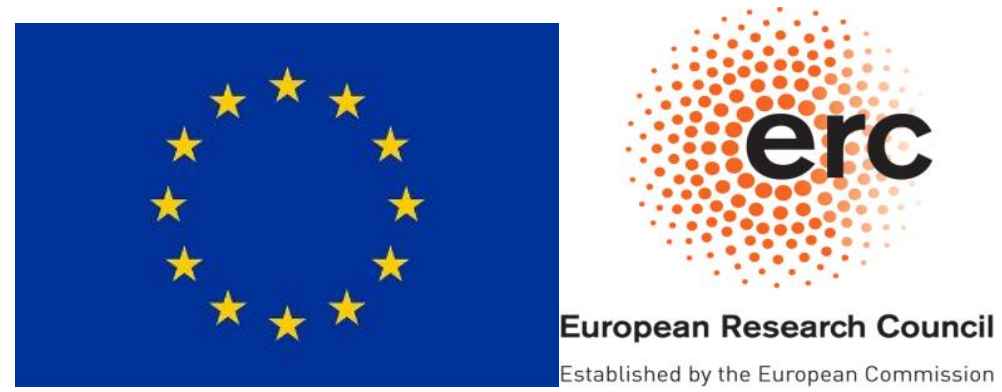


\section{ENTREPRENEURSHIP AND SUSTAINABILITY ISSUES}

ISSN 2345-0282 (online) http://jssidoi.org/jesi/ 2020 Volume 8 Number 2 (December)

http://doi.org/10.9770/jesi.2020.8.2(55)

Make your research more visible, join the Twitter account of ENTREPRENEURSHIP AND SUSTAINABILITY ISSUES: @Entrepr69728810

suitability of the analytical method tested are verified. Practical knowledge to deal with the situation in the region of South Bohemia was also obtained. The positively influencing factors for the economic potential of the region include the trend of increasing the number of people with university education, public transport services on weekdays, nursery facilities and population density. Negative factors include the natives and availability of secondary schools with the Maturita exam and landscape fragmentation. Within the mathematical modelling, it is possible to simulate the positive and negative response of additional inputs to the tested factors.

Keywords: economic potential; rural space; Stepwise backward analysis; Summary economic model; Sub-model

Reference to this paper should be made as follows: Pártlová, P., Dvořáková Lišková, Z., Felcan, M., Straková, J., Váchal, J., Polomský, J. 2020. New Approach to determining the economic potential of rural area on the example of the South Bohemian region of The Czech Republic. Entrepreneurship and Sustainability Issues, 8(2), 914-931. http://doi.org/10.9770/jesi. 2020.8.2(55)

JEL Classifications: O31, L26, C12

\section{Introduction}

Economic potential (business potential in particular as its most important component) is described as a limiting factor for the rural area, its sustainability and development. In the rural areas, mostly the SMEs operate, and they are the backbone of every national economy within the European Economic Area (Kramoliš \& Dobeš, 2020). Rural entrepreneurship is defined as entrepreneurial activities embedded in a distinctive environmental space, predominantly with local and regional scope, with a large spatial dimension, low settlement rates and often imperfect structures (Kalantaridis and Bika 2006b; Korsgaard, Muller, Tanvig 2015).

Another characteristic is related to the creation of new values, based on the use of resources from the environment (Razvanta 2019). It is a fact that the share of rural areas within the EU, and in the Czech Republic is between 60$70 \%$. Despite such dominance in terms of acreage, there is not yet an exact anchoring of the definition of rural space in the valid legislation of the Czech Republic (similarly in some EU countries). The reason is the ambiguous and polarized space, as there are different rural regions. These regions have different development potentials (Perlín, 2010; Skála, 2017). Many authors agree that the definition of rural areas should be derived from the characteristics of rural business, which is still a decisive and also limiting factor for rural stability. Business activities are gaining in diversity by ensuring the diversification of the social and social climate. At the same time, however, they are severely restricted in rural areas in some regions (Korsgaard et al. 2015; Dubois 2016; Bosworth, Turner 2018).

In the countries of the European Union, the rural areas cover an area of approximately $1,928.7 \mathrm{~km} 2$, i.e. $42.3 \%$ of the geographical surface of the European Union. These areas are populated by 82 to 97 million citizens (World Bank, Eurostat). These data indicate that one in four citizens of this economic and political group lives in rural areas. Many of them are in the middle and lower property class (Barczyk, Musial, Zukovskis 2019, Anyakoha, 2019). Outside the EU, such situation is even clearer, especially in rural areas of developing countries (Ksoll, Lilleor, Lonborg, Rasmussen 2016). Worldwide rural business employs about $40 \%$ of the world's population (AgFunder 2017). This amount contributes to $30 \%$ of GDP in developing countries (Mayorova, Domzal, Gernego, Dyba 2019). On the contrary, in EU countries it is more than 60\%. Therefore, understanding rural vitality and viability is an important research problem at the beginning of the $21^{\text {st }}$ century.

Rural vitality is defined as an area where strong, active and inclusive relations between the citizens, private space, public space and civil society organizations co-operate in economic, social and environmental space. Due to the growth of urban agglomerations, interest in a certain type of rural areas is increasing, including the use of their 


\section{ENTREPRENEURSHIP AND SUSTAINABILITY ISSUES}

ISSN 2345-0282 (online) http://jssidoi.org/jesi/ 2020 Volume 8 Number 2 (December)

http://doi.org/10.9770/jesi.2020.8.2(55)

Make your research more visible, join the Twitter account of ENTREPRENEURSHIP AND SUSTAINABILITY ISSUES: @Entrepr69728810

production areas. These production rural areas are becoming areas for housing, recreation of the urban residents, and also for the useful production capacity, as seen in many places in the Czech suburban countryside (Eimermann, Karlsson 2018).

The rural space of the Czech Republic went through a turbulent development in the last century. A major turning point came in 1989, when its historical mission, traditions, including crafts and small businesses returned to the Czech rural area. At the same time, however, negative tendencies, such as socio-economic inequality compared to urban regions started occurring (Blažek and Netrdová 2012). Such a negative trend is also relatd to a significant decline in the population from these peripheral, non-developing regions, in particular the outflow of professionally qualified and university-educated people (Ouředníček et al. 2011). Progressive activities, skilled work and university educated people are concentrated in dynamically forming metropolitan areas while rural areas are stagnant (Ouředníček et al. 2011; Hampl, Marada 2016) Business activities are disappearing from many rural settlements. Enterprises with predominant craft and agricultural production disappear or move to larger conurbations. Insufficient services and facilities are also apparent in the countryside. The frequency of public transport is decreasing. Job opportunities are limited, and the social and cultural activity of the population is declining (Korauš et al. 2020). However, these phenomena do not occur everywhere and to the same extent (Perlín et al. 2010; Novák and Netrdová, 2011; Jašková, 2019).

At the beginning of the $21^{\text {st }}$ century, scientific work increased its importance, declaring the need to ensure sustainable development, stability and a suitable business environment for the SMEs in rural regions (Ammirato, Felicetti, Della Gala, Frega 2017; Lazikova et al. 2018; Mészáros, Divékyová, 2019; Mura, Kajzar, 2019; Mura et al. 2018; Horváth, Hollósy, 2019). The rural areas often face problems associated with reduced economic and development capacity. Furthermore, these areas are associated with lower profitability, low economic potential, and the development of community planning. (Horiuchi 2017; Steiner; Teasdale 2019; Azhaman; Petryshchenko 2019, Belas et al. 2016, Dobrovič et al. 2018, Dobrovič et al. 2016). As a result of the downturn of the traditional handicrafts in the country, the predominant incomes from non-agricultural sources are important. The share of agricultural income continues to decline, right now at a slower pace (Pastusiak 2017; Barczyk et al. 2019). This process is exacerbated by the outflow of young people from the rural areas (Bosworth, Turner 2018). For this reason, the development of the rural areas is one of the main objectives of the development policy of the European Union. However, there is still no single approach to its definition and measurement (Straka, Tuzova 2016; Milone, Ventura 2010). The traditional model used is based on the hypothesis that, in rural areas, agriculture, in general, is considered to be often the only and main source of income that helps to foster rural development (Singgalen et al. 2019; Seilerová 2019).

The region of South Bohemia is characterized by its incompactly distributed settlement structure and low population density in contrast to a relatively large area. Due to the absence of more large towns, the region of South Bohemia is perceived as an area with a high proportion of agricultural, forestry and fishing activities. The localization of the region falls mostly in the area of the south of Bohemia.

With its area of $10,056 \mathrm{~m}^{2}$ (of the total area of $12.8 \%$ from the Czech Republic), the South Bohemian region is the second largest, in terms of the population of 643,176 it is the $6^{\text {th }}$ most populous region in the Czech Republic. The population density per square kilometre is 63.95. In terms of percentage of population living in small municipalities (classified up to 200 inhabitants), it is $4.3 \%$, and compared to the number of these municipalities it is $37.4 \%$, and $63.8 \%$ of the population living in the towns. Comparing the present character of settlement (population and landscape population, visual stability of settlements, density of settlements, etc.), character of agriculture (size of land, type of livestock buildings) and character of surrounding cultural landscape, South 


\section{ENTREPRENEURSHIP AND SUSTAINABILITY ISSUES}

ISSN 2345-0282 (online) http://jssidoi.org/jesi/ 2020 Volume 8 Number 2 (December)

http://doi.org/10.9770/jesi.2020.8.2(55)

Make your research more visible, join the Twitter account of ENTREPRENEURSHIP AND SUSTAINABILITY ISSUES: @Entrepr69728810

Bohemia is defined as the rural region. The position and role of the South Bohemian countryside is quite significant on a nationwide scale as the rural character creates significant disparities throughout the region. During its operation, the region deals with the problems typical the rural area. This is mainly due to an imbalance in terms of the availability of some services, or not to a fully developed infrastructure. Especially in the peripheral parts of the region, but also in the border area, there are rural areas whose stability and development are limited by factors such as worsening and increasing transport accessibility, lower availability of job opportunities, public services including cancellations of post offices, schools, shops and low support for small and medium-sized enterprises, etc.

Effective, sustainable and feasible solution of rural space in terms of its prosperity and development presupposes knowledge of its regional (economic, business) potential (Orynbassarova et al. 2019; Selivanova-Fyodorova et al. 2019; Perlín, 2008). By Skála (2017), the development potential is a complex of possibilities providing preconditions for further development of the municipality and increase the quality of life of the inhabitants in the countryside (Sobczyk, 2014). Development potential can be seen as a certain impulse that will stimulate and accelerate development (Hoggart and Buller, 2016; Štefko 2019; Vlacseková 2019). Development potential is defined by disposition, abilities and capacities that will lead to a positive change from the current situation in the future (Leitmanová et al., 2012, Rák 2012). Identifying development potential, and identifying key development factors, is an important knowledge for properly targeting development activities and payment security (Korauš et al. 2019a, Korauš et al. 2019c, Kopencova 2020; Rajnoha et al. 2017). In theories of regional development, factors are divided into exogenous and endogenous. In practice, these factors are not fundamentally opposed; however, they rather complement each other. Exogenous approaches express initiated development from the outside, which is dependent on external incentives and interventions, especially by the state. On the other hand, endogenous approaches, where development cannot be achieved solely by support from above, they need to be based on the bottom approach (Chromý, Skála 2010; Chromý et al. 2011; Okanazu et al. 2019; Kijek, MatrasBolibok, 2020), depend on local impulses and resources, initiative and active participation of local and regional actors. These interdependent and conditional potentials have different character and different influence on the development of rural space. (Bernard ed. 2011).

This paper focuses on the issue of determining the development, i.e. the economic potential, in the region.

\section{Methods}

The research used secondary data from Ekotoxa. The data were divided into four pillars (economic, social, infrastructure-institutional and environmental). In total, 602 municipalities in 17 local action groups of the South Bohemian Region were analyzed, except for towns with a population of over 25,000 , i.e. all municipalities that may be part of a regional LAG. A total of 29 indicators were selected. The proposed and subsequently selected indicators were consulted by CzechInvest and some adjustments of the indicators were made by Ekotoxa.

Finally, four indicators were selected in the economic; seven indicators in the social pillar; eleven indicators in infrastructure; and seven indicators in the environmental pillar. The indicators were assigned codes from K101 to K407, see Table 1. 
ENTREPRENEURSHIP AND SUSTAINABILITY ISSUES

ISSN 2345-0282 (online) http://jssidoi.org/jesi/ 2020 Volume 8 Number 2 (December)

http://doi.org/10.9770/jesi.2020.8.2(55)

Make your research more visible, join the Twitter account of ENTREPRENEURSHIP AND SUSTAINABILITY ISSUES: @Entrepr69728810

Table 1. Indicators of the pillars

\begin{tabular}{|c|c|c|c|}
\hline KOD & Economic pillar & K304 & $\begin{array}{l}\text { Accessibility of the area by the public } \\
\text { transport on Saturday }\end{array}$ \\
\hline K101 & Progressivity Index of the Economic Structure & K305 & Accessibility of the area by $\mathrm{A}$ and major roads \\
\hline K102 & $\begin{array}{l}\text { Trend of Progressivity Index of the Economic } \\
\text { Structure }\end{array}$ & K306 & Accessibility of railway stations \\
\hline K103 & Rate of Business Activity & K307 & $\begin{array}{l}\text { Residents living in permanently occupied } \\
\text { dwellings connected to water supply, gas and } \\
\text { public sewerage }\end{array}$ \\
\hline K104 & Natural Presumptions of Recreation & K308 & Nursery school facilities \\
\hline KOD & Social pillar & K309 & Primary school facilities \\
\hline K201 & Population Density & K310 & $\begin{array}{l}\text { Accessibility of secondary schools with } \\
\text { Maturita }\end{array}$ \\
\hline K202 & $\begin{array}{l}\text { Aging of Population (increase of the number of } \\
\text { senior citizens) - Aging index trend }\end{array}$ & K311 & Accessibility of senior care homes \\
\hline K203 & Economic load index trend & KOD & Environmental pillar \\
\hline K204 & Natives & K401 & Production capacity of land resources \\
\hline K205 & $\begin{array}{l}\text { Trend in the growth of the population with higher } \\
\text { education }\end{array}$ & K402 & Ecological fragmentation \\
\hline K206 & Unemployment trend & K403 & Share of water areas \\
\hline K207 & Czech citizenship & K404 & Chemical status of surface water \\
\hline KOD & Infras tructure pillar & K405 & Soil visualization trend \\
\hline K301 & $\begin{array}{l}\text { Accessibility of the area by the public transport on } \\
\text { weekdays }\end{array}$ & K406 & Forest hazard zones \\
\hline K302 & $\begin{array}{l}\text { Accessibility of the area by the public transport on } \\
\text { Saturday }\end{array}$ & K407 & $\begin{array}{l}\text { Trend of specific territorial emissions from } \\
\text { stationary source }\end{array}$ \\
\hline K303 & Accessibility of the area by $\mathrm{A}$ and major roads & & \\
\hline
\end{tabular}

The analytical tool used was the Stepwise Backward Analysis, a method of backward step regression for the calculation of economic models of the region of South Bohemia. Using this method, the dependence of other factors on the economic pillar factors was tested with the aim of projecting the most optimal economic pillar model for the rural area of the region of South Bohemia.

The method of gradual regression is the method of finding the most appropriate model (the smallest number of independent variables, the highest quality prediction). The subject of the analysis is not to determine the order of variables (predictors) in terms of their entry into the model; this is a part of the algorithm of the program itself. The programme is used in two variants - forward and backward. A reverse variant was used, in which all predictors are included first and then gradually removed and their significance within the tested indicator is analysed.

The principle of gradual regression is that the regression model is built step by step by examining all the predictors in each step to determine which of them best describes the variability of the dependent variable.

Both the inclusion of the predictor into the model and its exclusion is done by sequential F-tests. The sequential F-test is based on the F statistic, which is the ratio of the increment of the regression sum of squares when the predictor is included in the model and the residual sum of the squares. If this statistic is greater than the value 
Make your research more visible, join the Twitter account of ENTREPRENEURSHIP AND SUSTAINABILITY ISSUES: @ Entrepr69728810

called " $F$ to enter", the predictor is included. If the F statistic is less than the value called " $F$ to remove", the previously included predictor is excluded from the model.

After determining the variables into the model, the parameters of the linear regression function are estimated, and the quality of the regression is assessed by the determination index. Additional variables are gradually added to the model as the proportion of the explained variability of the magnitude increases.

Before the research, two research questions were formulated: The first one is related to the design of an economic model that would allow determining the economic potential of the territory; the second question focuses on finding and verifying a suitable analytical method for the proposed models. A partial objective was the real results of the research, in terms of usability and informative value for the users of results.

\section{Results and discusion}

3.1 Projection of the model for the analysis of regional economic potential

To analyse the economic potential of rural areas, a "Global Economic Model - GEM" is proposed consisting of four "Sub-Models - SM 1 to 4" used as a potential basis for the analysis of regional economic potential:

- Sub Model 1: Progressivity Index of Economic Structure (INXPES).

- Sub Model 2: Economic Structure Index Trend (TIES).

- Sub Model 3. Business Activity Rate (BAR).

- Sub Model 4: Recreation and Tourism Index (RATI).

Due to the limited extent of the paper, the analysis procedure for the Progressivity Index of the Economic Structure and the Trend of the Economic Structure Index are presented in full.

\subsubsection{The index of progressive economic structure}

The index of progressive economic structure (INXPES) is identified by the researchers as the decisive territorial index, determining the socio-economic differentiation of the regions in the Czech Republic. It is designed and constructed as a weighted sum of the proportion of the economically active enterprises in the primary sector, twice the proportion of the economically active in the secondary sector and three times the proportion of the economically active in the tertiary sector.

The algorithm of the method is that through its use, the explanatory variables are determined in the economic model of the regression function so that all the explanatory variables are initially included in the resulting model. In the next steps, the variable with the largest $\mathrm{p}$ value (i.e. the least statistically significant variable) is removed. This is done until an optimal regression model is found. Using the stepwise backward regression method, six explanatory variables are found that influence the progressive index of the economic structure. The resulting regression model is as follows:

$$
M p=\hat{y}=\beta_{0}+\beta_{1} X_{1}+\beta_{2} X_{2}+\beta_{3} X_{3}+\beta_{4} X_{4}+\beta_{5} X_{5}+\beta_{6} X_{6}
$$

$\mathrm{Mp}=\hat{y}$ - sample (empirical) regression function - complete model

Each $\beta_{i}$ for each indicator in the table is labelled as Estimates Beta.

The resulting regression function is as follows: 
ENTREPRENEURSHIP AND SUSTAINABILITY ISSUES

ISSN 2345-0282 (online) http://jssidoi.org/jesi/ 2020 Volume 8 Number 2 (December)

http://doi.org/10.9770/jesi.2020.8.2(55)

Make your research more visible, join the Twitter account of ENTREPRENEURSHIP AND SUSTAINABILITY ISSUES: @Entrepr69728810

$$
\begin{aligned}
& \hat{y}=2,600-0,006 x_{1}+0,006 x_{2}+0,001 x_{3}-0,014 x_{4}-0,003 x_{5}+0,188 x_{6} \\
& \text { and: } \\
& x_{1}=K 204 \text { The natives } \\
& x_{2}=K 205 \text { Trend in the growth of the population with higher education } \\
& x_{2}=K 205 \text { Accessibility of the area by the public transport on weekdays } \\
& x_{4}=K 306 \text { Nursery school facilities } \\
& x_{5}=K 308 \text { Accessibility of secondary schools with Maturita } \\
& x_{6}=K 402 \text { Landscape fragmentation }
\end{aligned}
$$

The input data for the input factors $\mathrm{x}_{1}$ to $\mathrm{x}_{6}$ are analysed using the regression equation. The results of the analysis are shown in Table 2.

Table 2. The index of progressive economic structure

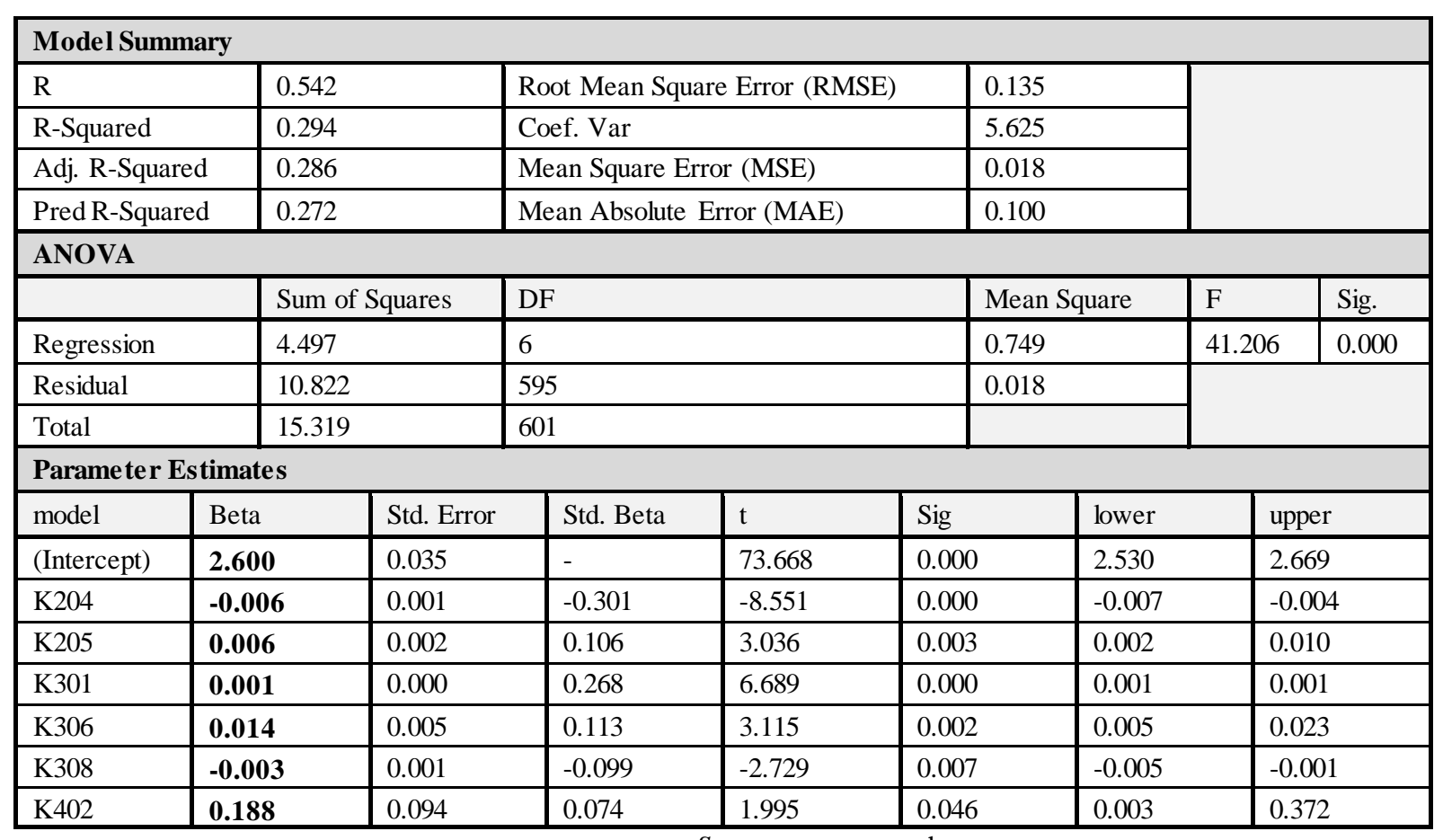

Source: own research

The authors use the following procedure to present the results of the analysis of the sub-models:

a) Assessment of the value of signification.

By the results shown in Table 2, the value of signification is 0.000 (the value below 0.05 ), in the sample, so that there are strong relations between the variables. 


\section{ENTREPRENEURSHIP AND SUSTAINABILITY ISSUES}

ISSN 2345-0282 (online) http://jssidoi.org/jesi/ 2020 Volume 8 Number 2 (December)

http://doi.org/10.9770/jesi.2020.8.2(55)

Make your research more visible, join the Twitter account of ENTREPRENEURSHIP AND SUSTAINABILITY ISSUES: @ Entrepr69728810

\section{b) Intensity of multiple dependences in the tested model.}

The aim is to determine the variability of the analysed set of variables for the tested index. The intensity of multiple dependencies is characterized by a multiple correlation coefficient, which is the square root of R-squared adjusted (see the table above).

$$
r_{B}=\sqrt{0,286}=0,534789
$$

By the value of R-squared adjusted (the adjusted index of determination) shown in Table 2, it is revealed that the combined action of all six explanatory variables (natives, the trend of population growth with tertiary education, public transport on weekdays, nursery facilities, availability of secondary schools with Maturita and ecological fragmentation) $28.6 \%$ variability of the explained variable of the progressive index of economic structure is explained.

c) Determining the directions of action of the test factors (positive and negative effects on the test index).

As shown in Table 2 (Beta column), the following factors influence the economic structure of the South Bohemia: Trend in the growth of the population with higher education, Transport services of the territory by public transport on weekdays, Nursery facilities and Landscape fragmentation. Regarding landscape fragmentation, the significance is not considerable and therefore there is no indication of the relation to the tested index. However, by the authors it also expresses the limiting value for the progressivity index of the economic structure. The factor of the natives and the availability of secondary schools with Maturita are negative.

d) Practical (point values) expression of a benefit and loss for each factor tested.

As shown in Table 2 (Model, Beta and Significance factors), it is possible to carry out a point-value or financial calculation (assuming the value of one point is defined, the authors are currently working towards the methodology within the proposed method).

The resulting regression model revealed that increasing the trend of increasing the number of inhabitants with higher education, transport services of the territory by public transport on weekdays and Nursery school facilities by one point increases the progression index model by $0.006,0.001$ and 0.014 points, assuming that the values of the other variables are unchanged. The opposite trend occurs in the factors of the natives and availability of secondary schools with Maturita - an increase of one point decreases the value of the index of economic structure of the region by 0.006 and 0.003 points.

For the landscape fragmentation factor, where the Significance Value is 0.046 , benefit modelling is irrelevant as there is no relation to the other factors.

e) Description of the factors by the results.

\section{- The Natives:}

The natives are related to the share of inhabitants born in the municipality of habitual residence. They usually have a stronger relationship with their native village. Also, the life in a micro-region offers certain life benefits for inhabitants born there; however, it might not be so attractive to other residents that moved in. It is assumed that a higher proportion of the natives is a sign of some developmental stagnation and higher degree of peripheral nature.

- Trend in population growth with higher education:

University educated population and its trend is an important indicator defining the quality and quantity of human resources, influencing the employment in the territory, development of the business environment, overall economic development of the territory, and also the functioning of the municipalities. In the area of human resources, the South Bohemian region is facing a shortage of labour, and a long-term trend of increasing the 


\section{ENTREPRENEURSHIP AND SUSTAINABILITY ISSUES}

ISSN 2345-0282 (online) http://jssidoi.org/jesi/ 2020 Volume 8 Number 2 (December)

http://doi.org/10.9770/jesi.2020.8.2(55)

Make your research more visible, join the Twitter account of ENTREPRENEURSHIP AND SUSTAINABILITY ISSUES: @ Entrepr69728810

number of job applicants not meeting the demands of the employers, including the university graduates. The main problems are mostly related to the decreasing interest in technical disciplines and inconsistency between the employers' requirements and the profiles of school graduates.

The region of South Bohemia, in comparison with the other regions, is rated as the average. The areas near České Budějovice (such as Hlubocko-Lišovsko, Netolicko) report the best situation. To the contrary, the areas of střední Povltaví, Blatensko, Bechyňsko (LAG Lužnice) are rand as the worst.

- Transport services of the territory by public transport on weekdays

The indicator defines the quantity of bus and railway connections, and the level of transport services to the municipality from other territories, otherwise defined as transport accessibility. The number of public transport connections in the region of South Bohemia is one of the lowest in the Czech Republic and it is 42 connections (14 ${ }^{\text {th }}$ among all the regions). The lack of public transport services is particularly difficult in small municipalities located on the outskirts of the region. On the other hand, the regions around the regional town of České Budějovice (LAG Hlubocko-Lišovsko, LAG Růže, LAG Pomalší) report excellent transport services.

Transport services are also defined using the term transport accessibility. Transport accessibility is understood as a structural morphological feature of the communication network, as communication availability of nodes. Accessibility is understood as the ability of a territory to be reached and to reach various other sites. Availability significantly affects the spatial organization and structure of the cultural landscape. Increasing availability regulates the economic development of the settlements. Higher number of connections in the municipality determines higher accessibility of the municipality, indicated as attractiveness and emtivity (potential of the settlements to create interactions) of the territory.

- Nursery school facilities

Most nursery school facilities are located in larger towns and centres of municipalities with extended powers. Most nursery schools are located in large towns with the population over 10,000 inhabitants. On the other hand, the lowest number of nursery schools is in municipalities with less than 300 inhabitants. It was also verified that the municipalities with the population over 1,000 occupy $64 \%$ of the total number of the nursery schools in the region and are better equipped with pre-school education compared to the municipalities with a lower population. There is sort of a direct and proportional link, as a larger population means more children and consequently a higher demand for pre-school facilities.

- Accessibility of secondary schools with Maturita

In the region of South Bohemia, more than half of the secondary technical schools and vocational schools are concentrated in district towns. Those interested in studying here have a greater choice of study and teaching fields. However, many schools are also located in other towns, and their focus often results from the economic and geographical conditions and traditions of the region. The largest number of pupils is in general preparation, i.e. the grammar schools, the second largest group of secondary school classes is in the field of Mechanical Engineering and Manufacturing, and in proportion to the other groups their number is increasing steadily, especially in recent years. This is largely due to a wide choice of the support for technical education, followed by agriculture and forestry and gastronomy, hotel and tourism. The ranking of the first three places has been the same for the third year.

- Landscape fragmentation 
Make your research more visible, join the Twitter account of ENTREPRENEURSHIP AND SUSTAINABILITY ISSUES: @Entrepr69728810

With regard to the environmental character of the region, fragmentation of the landscape is generally a negative factor, assuming that a stable landscape is the basis for healthy and sustainable economic growth of the territory. One of the main reasons for landscape fragmentation is primarily related to the construction and use of linear transport infrastructure, in addition to agricultural production and urbanization. This includes roads, railways and waterways. Linear routes divide the territory they pass through into smaller and smaller parts, fragmenting the area, affecting the life in the landscape negatively. Fragmentation of the landscape is related to nature conservation and it is also irreplaceable for the life of humans in rural space and for the stability in the arras. Fragmentation barriers in nature reduce the landscape potential for recreation and the permeability of the landscape to allow free movement. The landscape divided into small segments by settlements and transport, with consequent noise and emission load, is losing the potential. In summary, the fragmentation of the landscape in the region of South Bohemia will grow in the future by building a motorway, road and rail network, urbanization and construction of buildings for business activities; thus, a negative impact on the economic potential of the territory is expected.

\subsubsection{Economic Structure Index Trend}

Economic Structure Index Trend (TIES) is the second partial model tested in the total model. The trend follows the analysis of changes in the sectoral structure of employment in terms of the current level and its future potential. Using the stepwise backwards regression method, two explanatory variables are selected that significantly affect the progressive index of the economic structure. The resulting regression model is as follows:

$$
M p=\hat{y}=\beta_{0}+\beta_{1} X_{1}+\beta_{2} X_{2}
$$

$\mathrm{Mp}=\hat{y}$-sample (empirical) regression function - complete model

Each $\beta_{i}$ for each indicator in the table is labelled as Estimates Beta.

$$
\hat{y}=0,186+0,000 x_{1}-0,242 x_{2}
$$

$x_{1}=K 201$ Population density

$x_{2}=K 402$ Landscape fragmentation

The input data for the input factors $\mathrm{x}_{1}$ and $\mathrm{x}_{2}$ are analysed using the regression equation. The results of the analysis are shown in Table 3.

\begin{tabular}{|c|c|c|c|c|c|}
\hline \multicolumn{6}{|c|}{ Model Summary } \\
\hline $\mathrm{R}$ & 0.166 & Root Mean Square Error (RMSE) & 0.136 & & \\
\hline R-Squared & 0.028 & Coef. Var & 80.779 & & \\
\hline Adj. R-Squared & 0.024 & Mean Square Error (MSE) & 0.018 & & \\
\hline Pred R-Squared & 0.020 & Mean Absolute Error (MAE) & 0.093 & & \\
\hline \multicolumn{6}{|l|}{ ANOVA } \\
\hline & Sum of Squares & DF & Mean Square & $\mathrm{F}$ & Sig. \\
\hline Regression & 0.313 & 2 & 0.156 & 8.49 & $2 \mathrm{e}-04$ \\
\hline Residual & 11.006 & 598 & 0.018 & & \\
\hline Total & 11.319 & 600 & & & \\
\hline
\end{tabular}

Table 3. Economic Structure Index Trend 
ENTREPRENEURSHIP AND SUSTAINABILITY ISSUES

ISSN 2345-0282 (online) http://jssidoi.org/jesi/ 2020 Volume 8 Number 2 (December)

http://doi.org/10.9770/jesi.2020.8.2(55)

Make your research more visible, join the Twitter account of ENTREPRENEURSHIP AND SUSTAINABILITY ISSUES: @ Entrepr69728810

\begin{tabular}{|l|l|l|l|l|l|l|l|}
\hline model & Beta & Std. Error & Std. Beta & $\mathrm{t}$ & Sig & lower & upper \\
\hline (Intercept) & 0.186 & 0.007 & - & 25.875 & 0.000 & 0.172 & 0.201 \\
\hline K201 & 0.000 & 0.000 & -0.098 & -2.361 & 0.019 & 0.000 & 0.000 \\
\hline K402 & -0.242 & 0.090 & -0.112 & -2.685 & 0.007 & -0.420 & -0.065 \\
\hline
\end{tabular}

Source: own research

The following procedure is used to present the results of the analysis of the sub-model:

a) Assessment of the value of signification.

As revealed by the significance of 2e-04 (value below 0.05), there are strong links of the variables in the sample.

b) Intensity of multiple dependences in the tested model

The intensity of multiple dependencies is characterized by a multiple correlation coefficient, which is the square root of R-squared adjusted (see the table above).

$$
r_{B}=\sqrt{0,024}=0,1549
$$

As revealed by the value of $\mathrm{R}$-squared adjusted (adjusted index of determination), the joint action of two explanatory variables (settlement density and ecological fragmentation) explains $2.4 \%$ of the variability of the explained variable of the economic structure index trend.

c) Determining the directions of action of the test factors (positive and negative effects on the test index).

The Population Density Factor has a positive effect on the trend of the economic structure index. The opposite, i.e. negative, direction of action is indicated for the landscape fragmentation factor.

d) Practical (point values) expression of a benefit and loss for each factor tested.

The regression model also suggests that increasing the population density by one point will not change the trend of the economic structure index, although a positive effect is assumed if the other variables are unchanged. The opposite trend, i.e. the negative effect on the Index, is reported for the factor of landscape fragmentation, as an increase of this factor by one point results in a decrease in the value of the trend of the economic structure index of the region by 0.242 points.

e) Description of the factors by the results.

The linear model proves a dependence on population density and landscape fragmentation. Population density usually indicates the attractiveness of the territory, including sufficient cultural development in the region. The sufficient amount of human resources also predicts a certain direction in land use. The possible negative effects of this factor include the case of extreme population density, which would be in conflict with the potential economic capacity of the territory, which is not possible in the region of South Bohemia.

Increased value of the landscape fragmentation is usually related to intensive development of residential, industrial and transport infrastructure, greater urbanization of the territory, and the division of natural localities, which may have a negative impact on the attractiveness of the area and on its ecological stability. Migration barriers are landscape structures that prevent the free movement of animals. In terms of the calculation of the fragmented area, the following groups were selected as the main barriers: motorways and expressways, roads I, II. III. class, double - track and other railways. Therefore, this indicator is also defined by the fact that the higher the degree of fragmentation of the territory, the better, high-quality and faster transport service to the region. The least fragmented area is the area of Trhové Sviny and Nové Hrady (LAG Růže), the whole area of Šumava (LAG Šmavsko and LAG Rozkvět) and LAG Blanský les and Netolicko. 
ENTREPRENEURSHIP AND SUSTAINABILITY ISSUES

ISSN 2345-0282 (online) http://jssidoi.org/jesi/

2020 Volume 8 Number 2 (December)

http://doi.org/10.9770/jesi.2020.8.2(55)

Make your research more visible, join the Twitter account of ENTREPRENEURSHIP AND SUSTAINABILITY ISSUES: @ Entrepr69728810

Similarly, the remaining two partial models were tested, in particular the business activity rate and recreation and tourism index.

\section{Results and Discussion}

Before the research, two research questions were formulated: The first one is related to the design of an economic model that would allow determining the economic potential of the territory; the second question focuses on finding and verifying a suitable analytical method for the proposed models. A partial objective was the real results of the research, in terms of usability and informative value for the users of results. The following par of summary and recommendations discusses the fulfilment of the above-mentioned objectives.

Before testing the comprehensive economic model, the structure of the economic pillar was proposed, consisting of 31 indicators reflecting the specificities of the regions in the Czech Republic. The final scope can be determined only after the general application in all the regions in the Czech Republic. However, their number and structure are sufficient for the region of South Bohemia.

Prospectively, there is a need to precisely define the procedure for collecting relevant secondary and primary data, to specify the minimum extent of the reference period, to define the qualitative aspect of the data base and the form of data processing prior to the actual use for the analyses.

The proposed comprehensive economic model, consisting of four sub-models (Progressivity Index of Economic Structure, Trend of Economic Structure Index, Business Activity Rate and Recreation and Tourism Index), is suitable for expressing the current and predicted development capacity of the relevant territorial unit. The first sub-model is considered decisive in terms of socio-economic differentiation of individual regions within the state. The index of progressivity of the economic structure is described as a decisive territorial index in terms of regional differentiation, its construction (weighted sum of the share of economically active enterprises in the primary sector, double the share of economically active in the secondary sector and three times the share of economically active in the tertiary sector) is appropriate. The second index - The trend of the index of economic structure progressivity - is based on the data base of the development trend and it follows the analysis of changes in the sectoral structure of employment in terms of the current level and its future potential. The construction of this index also provides appropriate outputs; however, the range of analyzed factors (so far, there are two population density and landscape fragmentation) might increase.

The proposed procedure for the presentation of the results of the mathematical-statistical analyses is the first approximation of the solution with the assumption of its gradual refinement and completion. Regarding the structure of the output analytical report, the proposed procedure of evaluation of the results is evaluated in the following way: assessment of the signification value, intensity of multiple dependencies in the tested model, determination of directions of influence of the tested factors (positive and negative influence on the test index) benefits and losses of the factors and characteristics of the analyzed factors from the point of view of their suitability for management, administrative bodies and business practice.

In addition to the design of a comprehensive economic model and its four sub-models, another research objective was to design and validate an appropriate analytical method to ensure valid and applicable outputs into the social and business practice (Korauš et al. 2019). Stepwise backward analysis was chosen and tested based on the 


\section{ENTREPRENEURSHIP AND SUSTAINABILITY ISSUES}

ISSN 2345-0282 (online) http://jssidoi.org/jesi/ 2020 Volume 8 Number 2 (December)

http://doi.org/10.9770/jesi.2020.8.2(55)

Make your research more visible, join the Twitter account of ENTREPRENEURSHIP AND SUSTAINABILITY ISSUES: @Entrepr69728810

selection of suitable mathematical-statistical methods. It is not possible to make a final decision; however, in accordance with the obtained results, its usability for the required analyzes is proved. A part of the input (data) to the analysis tool is necessary to complete. The evaluation of the quality of regression by the determination index and the determination of the intensity of multiple dependences by means of multiple correlation coefficients are useful.

Regarding the practical outputs aimed at the region of South Bohemia, it is possible:

To point to the following conclusion related to the Progressivity Index of Economic Structure:

- The trend of increasing the number of people with university education, public transport services on weekdays, and nursery facilities are reported to be the positively influencing factors for the economic potential of the region of South Bohemia. The natives and availability of secondary schools with the Maturita exam are the negative factors. On this basis, the expected benefits and losses of additional financial deposits and investments were tested;

- Regarding the characteristics of the factors and the possibility of their use in terms of strengthening the economic potential of the region of South Bohemia, there are increased issues in the area of loss of skilled labour resources, including the university graduates, gradual but permanent loss of the native population, decrease of business activity, reduced level of service including transport, availability of secondary schools with Maturita exam is sufficient. The negative trend is related to in the departure of the students to study universities in other centres such as Prague, Brno and Plzeň. The strengthening trend of landscape fragmentation also does not contribute to strengthening the economic potential of the region.

To point to the following conclusion related to the Trend of the Progressivity Index of Economic Structure:

- Regarding the effect on the economic structure growth trend, there is a positive effect of the population density factor. The opposite, i.e. negative direction of action, is reported for the landscape fragmentation factor.

- In terms of the impact of the factors related to additional deposits, financial and other types, there is a zero response in case of the population density, although a positive effect is assumed provided the other variables are unchanged. On the other hand, the factor of landscape fragmentation has a negative financial effect, decreasing the trend index of the economic structure of the region, the most significantly of all the tested factors.

- The population density is one of the smallest in the Czech Republic and such trend continues. In the case of landscape fragmentation, a similar conclusion as in the previous index is reached; on the one hand the entrepreneurs welcome its increasing intensity, on the other hand there is an irreversible damage to the environment.

\section{Conclusions}

Many scientific workplaces both at home and abroad address the issue of stabilization and development of rural areas. The solution proves to be a limiting factor in ensuring the functionality of small and medium-sized enterprises in this area, as a decisive socio-economic accelerator and stabilizer for the rural areas. A prerequisite for a successful solution to the development of business activities is, however, knowledge of economic, and business potential. It is a fact that there is not a method available that would analyse, evaluate and present the business potential of the relevant area for its gradual fulfilment. The researchers respond to this fact and submit a new methodological procedure for scientific discussion that would respond to the real need of management and business practice. The results indicate both the appropriateness of the proposed methodical approach in terms of expertise and the suitability of the mathematical-statistical methods used, the way of presenting the results and their use in management and business practice. 


\section{ENTREPRENEURSHIP AND SUSTAINABILITY ISSUES}

ISSN 2345-0282 (online) http://jssidoi.org/jesi/ 2020 Volume 8 Number 2 (December)

http://doi.org/10.9770/jesi.2020.8.2(55)

Make your research more visible, join the Twitter account of ENTREPRENEURSHIP AND SUSTAINABILITY ISSUES: @Entrepr69728810

The authors are aware that this is the initial approximation of the results and some area of the methods need to be defined more precisely, and in particular, it is necessary to test the proposed model in a wider range. It is also necessary to precise the secondary data sample, to ensure their complementation and deepening by collecting the primary data with the preferential use of accessible database files. The presented results should support opening wider scientific discussion on the issue, which has long been lacking.

\section{References}

Agfunder, (2017). Year in Review 2017: AgFunder AgriFood Tech Investing Report. Available at: https://research.agfunder.com/2017/AgFunder-Agrifood-Tech-Investing-Report-2017.pdf

Ammirato, S., Felicetti, A., M., Della Gala, M., \& Frega, N., (2017). Sustainable Development for Rural Areas: A Survey on the Agritourism Rural Networks. Collaboration in a data-rich world. 506, pp. 564-574. https://doi.org/10.1007/978-3-319-65151-4_50

Anyakoha, C. (2019). Job analysis as a tool for improved organizational performance of SMEs in Lagos, Nigeria. Central Europe an Journal of Labour Law and Personnel Management, 2(1), 7-16. https://doi.org/10.33382/cejllpm. 2019.02.01

Azhaman, I., \& Petryshchenko, N., (2019). Development of construction investment in the rural area. Baltic journal of economic studies. 5(2), 1-9. https://doi.org/10.30525/2256-0742/2019-5-2-1-9

Barczyk, J., Musial, W., \& Zukovskis, J. (2019). Barriers and opportunities to the development of small business in rural areas. Management theory and studies for rural business and infrastructure development. 41(1), 114-125. ISSN $2345-0355$. https://doi.org/10.15544/mts.2019.11

Belás, J., Korauš, M., Kombo, F. \& Korauš, A. 2016. Electronic banking security and customer satisfaction and in commercial banks, Journal of Security and Sustainability Issues, 5(3), 411-422. https://doi.org/10.9770/jssi.2016.5.3(9)

Bernard, J., (2011). Endogenní rozvojové potenciály malých venkovských obcí - obtížné hledání a měření jejich vlivu (Endogenous development potentials of small rural communities - difficult to find and measure their impact). Sociologický časopis/Czech Sociological Review, 47(4), 745-775. https://www.jstor.org/stable/23073230

Blažek, J., \& Netrdová, P., (2012). Contemporary tendencies of the development of spatial pattern on the local level in Czechia: towards higher fragmentation of the spatial pattern? Geografie, 117(3), pp. 266-288. https://doi.org/10.37040/geografie2012117030266

Bosworth, G., \& Turner, R., (2018). Interrogating the meaning of a rural business through a rural capitals framework. Journal of rural studies, 60, 1-10. https://doi.org/10.1016/j.jrurstud.2018.02.002

Dobrovič, J., Rajnoha, R., \& Korauš, A. (2018). Effectiveness and performance of tax system in Slovak Republic in terms of its key nonmacroeconomics factors. Oeconomia Copernicana, 9(4). https://doi.org/10.24136/oc.2018.030

Dobrovič, J., Korauš, A., \& Dančišinová, L. 2016. Sustainable economic development of Slovakia: factors determining optimal tax collection, Journal of Security and Sustainability Issues, 5(4), 533-544. https://doi.org/10.9770/jssi.2016.5.4(7)

Dubois, A., (2016). Transnationalising entrepreneurship in a peripheral region - the translocal embeddedness paradigm. Journal of Rural Studies, 46, pp. 1-11. https://doi.org/10.1016/j.jrurstud.2016.05.003

Eimermann, M., \& Karlsson, S., (2018). Globalising Swedish countrysides? A relational approach to rural immigrant restaurateurs with refugee backgrounds. Norsk geografisk tidsskrift-norwegian journal of geography. 72(2), 82-96. https://doi.org/10.1080/00291951.2018.1450781

Hampl, M., \& Marada, M., (2016). Metropolization and regional development in Czechia during the transformation period. Geografie, 121(4), 566-590. https://doi. org/10.37040/geografie2016121040566 


\section{ENTREPRENEURSHIP AND SUSTAINABILITY ISSUES}

ISSN 2345-0282 (online) http://jssidoi.org/jesi/ 2020 Volume 8 Number 2 (December)

http://doi.org/10.9770/jesi.2020.8.2(55)

Make your research more visible, join the Twitter account of ENTREPRENEURSHIP AND SUSTAINABILITY ISSUES: @ Entrepr69728810

Hoggart, K., \& Buller, H., 2016. Rural development, Routledge, New York, 317 pp. ISBN-13: 978-0709937562

Horiuchi, S., (2017). Entrepreneurs' networks at rural market: developing a creative village in the Yamagata prefecture, Japan. Economics \& sociology. 10(3), 251-265. https://doi.org/10.14254/2071-789X.2017/10-3/18

Horváth, Zs., Hollósy, V. G. (2019). The revision of Hungarian public service motivation (PSM) model. Central European Journal of Labour Law and Personnel Management, 2 1), 17-28. https://doi.org/10.33382/cejllpm. 2019.02.02

Chromý, P., Jančák, V., Marada, M., \& Havlíček, T., (2011). Rural Areas - Living Space: Regional Differences in the Perceptions of Representatives of Rural Municipalities in Czechia Regarding Rural Areas. Geografie, 116(1), 23-45. https://doi.org/10.37040/geografie2011116010023

Chromý, P., \& Skála, J., (2010). Cultural-geographical aspects in the development of borderland peripheries: an analysis of selected elements of territorial identity among residents of the Sušicko region. Geografie, 115(2), 223-246. https://doi.org/10.37040/geografie2010115020223

Ievoli, C., Belliggiano, A., Marandola, D., Milone, P., \& Ventura, F., (2019). Information and communication infrastructures and new business models in rural areas: the case of Molise region in Italy. European Countryside. 11(4), pp. 475-496. https://doi.org/10.2478/euco$\underline{2019-0027}$

Jašková, D. (2019). Assessment of social development in Slovakia in the context of human resources. Central European Journal of Labour Law and Personnel Management, 2(2), 21-32. ISSN 2644-4917. https://doi.org/10.33382/cejllpm.2019.03.02

Kalantaridis, CH., \& Bika, Z. (2006). Local embeddedness and rural entrepreneurship: case-study evidence from Cumbria, England, Environment and Planning A, Pion Ltd, London, 38(8), pp. 1561-1579. https://doi.org/10.1068/a3834

Kijek, A., \& Matras-Bolibok, A. (2020). Technological convergence across European regions. Equilibrium. Quarterly Journal of Economics and Economic Policy, 15(2), pp. 295-313. https://doi.org/10.24136/eq. 2020.014

Kopencova, D. (2020). Secondary education with security focus. INTED 2020 Proceedings, pp. 2477-2481. 14th International Technology, Education and Technology and Development Conference. 2nd-4th March, 2020, Valencia, Spain. ISBN: 978-84-09-17939-8, ISSN: 23401079. https://doi. org/10.21125/inted.2020.0755 https://ibrary.iated.org/view/KOPENCOVA2020CZE

Korsgaard, S., Muller, S., \& Tanvig, H., W., (2015). Rural entrepreneurship or entrepreneurship in the rural - between place and space. International journal of entrepreneurial behaviour \& research. 21(1), 5-26. ISSN 1355-2554. https://doi.org/10.1108/IJEBR-11-2013-0205

Korauš, A., Gombár, M., Kelemen, P., \& Polák, J. (2019a). Analysis of respondents' opinions and attitudes toward the security of payment systems, Entrepreneurship and Sustainability Issues, 6(4), 1987-2002. https://doi.org/10.9770/jesi.2019.6.4(31)

Korauš, A., Kaščáková, Z., \& Felcan, M., (2020). The impact of ability-enhancing HRM practices on perceived individual performance in IT industry in Slovakia. Central European Journal of Labour Law and Personnel Management, 3(1), 33-45. https://doi.org/10.33382/cejllpm.2020.04.03

Kramoliš, J., \& Dobeš, K. (2020). Debt as a financial risk factor in SMEs in the Czech Republic. Equilibrium. Quarterly Journal of Economics and Economic Policy, 15(1), 87-105. https://doi.org/10.24136/eq.2020.005

Ksoll, C., Lilleor, H., B., Lonborg, J., H., \& Rasmussen, O., D., (2016). Impact of Village Savings and Loan Associations: Evidence from a cluster randomized trial. Journal of development economics, 120, 70-85. https://doi.org/10.1016/j.jde veco.2015.12.003

Lazikova, J., Bandlerova, A., Rohacikova, O., Schwarcz, P., \& Rumanovska, L. (2018). Regional Disparities of Small and Medium Enterprises in Slovakia. Acta Polytechnica Hungarica, Vol. 15, No. 8, pp. 227-246. https://doi.org/10.12700/APH.15.8.2018.8.12

Mayorova, T., Domzal, Z., Gernego, I., \& Dyba, O., (2019). High-technology investments as a driver of rural productivity. Management theory and studies for rural business and infrastructure development. 41(1), 25-32. https://doi.org/10.15544/mts.2019.03 
ENTREPRENEURSHIP AND SUSTAINABILITY ISSUES

ISSN 2345-0282 (online) http://jssidoi.org/jesi/ 2020 Volume 8 Number 2 (December)

http://doi.org/10.9770/jesi.2020.8.2(55)

Make your research more visible, join the Twitter account of ENTREPRENEURSHIP AND SUSTAINABILITY ISSUES: @ Entrepr69728810

Mészáros, M., \& Divékyová, K. (2019). Immediate termination of employment relationship by the employer. Central European Journal of Labour Law and Personnel Management, 2(2), 33-43. ISSN 2644-4917. https://doi.org/10.33382/cejllpm.2019.03.03

Milone, P. \& Ventura, F. (2019). New generation farmers: Rediscovering the peasantry, Journal of Rural Studies 65, pp. 43-52. DOI: https://doi.org/10.1016/j.jrurstud.2018.12.009

Mura, L., \& Kajzar, P. (2019). Small Businesses in Cultural Tourism in a Central European Country. Journal of Tourism and Services, 10(19), 40-54. https://doi.org/10.29036/jots.v10i19.110 ISSN 1804-5650

Mura, L., Marchevska, M., \& Dubravska, M. (2018). Slovak Retail Business Across Panel Regression Model. Marketing and Management of Innovations, 4, pp. 203-211. ISSN 2227-671

Novák, J., \& Netrdová, P. (2011): Prostorové vzorce sociálně-ekonomické diferenciace obcí v České republice. Sociologický časopis, 47(4), pp. 717-744. ISSN 0038-0288 (Print) ISSN 2336-128X (Online)

Okanazu, O.O., Madu, M.A., Igboke, S. A. (2019). A recipe for efficient and corrupt free public sector. Central European Journal of Labour Law and Personnel Management, 2(1), 29-46. https://doi. org/10.33382/cejllpm.2019.02.03

Orynbassarova, Y., Abzalbek, E., Pritvorova, T., Petrenko, Y. 2019. Regional and product profile of post-industrial services in the economy of Kazakhstan. Insights into Regional Development, 1(4), 343-355. https://doi.org/10.9770/ird.2019.1.4(5)

Ouředníček, M., Špačková, P., \& Feřtrová, M. (2011). Změny sociálního prostředí a kvality života v depopulačních regionech České republiky. Sociologický časopis/Czech Sociological Review, 47(4), 777-803. ISSN 0038-0288 (Print)

ISSN 2336-128X (Online)

Ouředníček, M., \& Temelová, J. (2011): Nové sociálně prostorové nerovnosti, lokální rozvoj a kvalita života. Sociologický časopis/Czech Sociological Review, 47(4)pp. 625-631. ISSN 0038-0288(Print) ISSN 2336-128X (Online)

Ouředníček, M., Temelová, J., \& Pospišilová, L. (2011). eds. Atlas sociálně prostorové diferenciace České republiky. Nakladatelství Karolinum, Praha, 137 p. ISBN 9788024618890

Pastusiak R., Jasiniak M., Soliwoda M., \& Stawska J. (2017). What may determine off-farm income? A review. Agric. Econ. - Czech, 63: 380-391. https://doi. org/10.17221/123/2016-AGRICECON

Perlín, R., \& Šimčíková, A. (2008). Criteria of a successful rural municipality. Europa XXI, 17, pp. 29-43. ISSN 1429-7132

Perlín, R., Kučerová, S., \& Kučera, Z. (2010): Typologie venkovského prostoru Česka. Geografie, 115(2) 161-187. ISSN 1212-0014 (Print) ISSN 2571-421X (Online)

Rajnoha, R., Korauš, A. \& Dobrovič, J. (2017). Information systems for sustainable performance of organizations, Journal of Security and Sustainability Issues, 7(1), 167-179. https://doi.org/10.9770/jssi.2017.7.1(14)

Rak, R, \& Zrubak, R.. (2012). Project eCALL - Car in Emergency Situation. 7th Scientific International Conference Crisis Management: Envirenmental Protection of Population - Conference Proceedings. Edited by Horak, R; Juricek, L; Schwarz, R. pp. 251-258, Proceedings paper, ISBN 978-80-86710-57-0.

Razvanta, F., (2019). Conceptual framework for rural business models. Proceedings of the international conference on business excellence. 13(1), 1130-1139. https://doi. org/10.2478/picbe-2019-0099

Seilerová, M. (2019). The Consequences of Psychosocial Risks in the Workplace in Legal Context. Central European Journal of Labour Law and Personnel Management, 2(1), 47-60. https://doi.org/10.33382/cejllpm.2019.02.04

Selivanova-Fyodorova, N., Komarova, V., Lonska, J, Mietule, I. (2019). Differentiation of internal regions in the EU countries. Insights into Regional Development, 1(4), 370-384. https://doi.org/10.9770/ird.2019.1.4(7)

Singgalen, Y.A., Sasongko, G., Wiloso, P.G. (2019). Community participation in regional tourism development: a case study in North Halmahera Regency - Indonesia. Insights into Regional Development, 1(4), 318-332. https://doi.org/10.9770/ird.2019.1.4(3) 
ENTREPRENEURSHIP AND SUSTAINABILITY ISSUES

ISSN 2345-0282 (online) http://jssidoi.org/jesi/ 2020 Volume 8 Number 2 (December)

http://doi.org/10.9770/jesi.2020.8.2(55)

Make your research more visible, join the Twitter account of ENTREPRENEURSHIP AND SUSTAINABILITY ISSUES: @Entrepr69728810

Skála, V. (2017). Vliv sociálního kapitálu na rozvojový potenciál venkovských obcí. Acta Politologica, FSV UK Praha, pp. 40-56. ISSN 1803-8220 (on-line) | ISSN 1804-1302 (print)

Sobczyk, W. (2014). Sustainable Development of Rural Areas: Problems of sustainable development, https://ssrn.com/abstract=2387299

Sobczyk, W. (2014). Sustainable Development of Rural Areas: Problems of sustainable development, https://ssrn.com/abstract=2387299

Steiner, A., \& Teasdale, S., (2019). Unlocking the potential of rural social enterprise. Journal of rural studies. 70, 144-154. https://doi.org/10.1016/j.jrurstud.2017.12.021

Straka, J., \& Tuzova, M., (2016). Factors Affecting Development of Rural Areas in the Czech Republic: A Literature Review. 19th international conference enterprise and competitive environment, 220, 496-505. https://doi.org/10.1016/j.sbs pro.2016.05.525

Štefko, M. (2019). Notice for reasons of redundancy as a measure for discrimination on grounds of age. Central European Journal of Labour Law and Personnel Management, 1(1), 61-73. https://doi. org/10.33382/cejllpm.2019.02.05

Vlacseková, D. (2019). Comparative analysis of motivation of civil servants and public servants in the local state administration - case study of Slovakia. Central European Journal of Labour Law and Personnel Management, 2(1), 74-93. https://doi.org/10.33382/ce jllpm.2019.02.06

\section{Acknowledgements}

This research was funded by Technology Agency of the Czech Republic, programme of ETA, project reg. no. TL01000349 Stabilization and development of SME in rural areas.
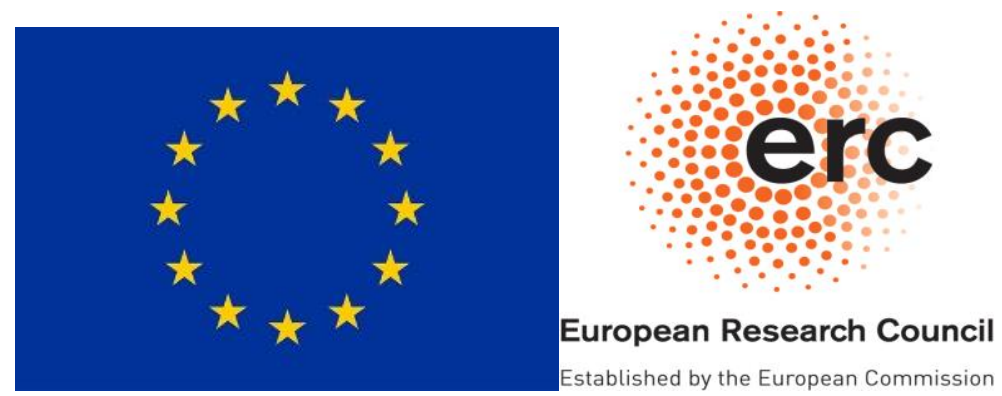
ENTREPRENEURSHIP AND SUSTAINABILITY ISSUES

ISSN 2345-0282 (online) http://jssidoi.org/jesi/ 2020 Volume 8 Number 2 (December)

http://doi.org/10.9770/jesi.2020.8.2(55)

Make your research more visible, join the Twitter account of ENTREPRENEURSHIP AND SUSTAINABILITY ISSUES: @Entrepr69728810

Petra PÁRTLOVÁ is a research assistant at the Department of Management of the at the Institute of Technology and Business in České Budějovice. Her research deals with the issues of corporate management, focusing on small and medium-sized enterprises (smes) and regional policy. She deals with the issues of external environment and sustainability and profit of small and medium sized businesses in the czech republic. Within the major changes, modifications of the corporate architecture are proposed. It is a fact that the production and economic and social base for smes is a rural area that is the subject of research within the territorial regionalism.

ORCID ID: https://orcid.org/0000-0003-2404-6073

Zuzana DVOǨ́́KOVÁ LÍŠKOVÁ works as a lecturer in the Department of Regional Development. In her research and pedagogic activity is involved in the topic of human impacts on the landscape in terms of ecological and socio-economic point of view. She also deals with the issue of sustainable regional development, possibilities of brownfields regeneration and strategic and tactical documents for public administration.

ORCID ID: https://orcid.org/0000-0003-1788-6808

Miroslav FELCAN is an associate professor at Academy of the Police Force in Bratislava, Slovak Republic. Research interests: administrative law, tax law, financial law, finance security, economic frauds, financial frauds, sustainability.

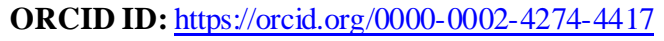

Jarmila STRAKOVÁ serves as associate professor and Deputy Head of the Managment Department at the Technical and Economic Institution in České Budějovice. The research work of the author focuses on the issues of strategic management of enterprises, especially on the analysis of the business environment and the value of the enterprise potential.

ORCID ID: $\underline{\text { https://orcid.org/0000-0002-3048-3467 }}$

Jan VÁCHAL is professor and head of the Department of Management at the Institute of Technology and Business in České Budějovice. His research focuses on the issues of corporate strategy, environment of enterprises and production potential, in different sectors of national economy. In a long-term, he deals with energy-mass flows in the landscape, issues of landscape engineering and the determination of production and environmental functions in natural and cultural ecosystems. Outputs from the research are implemented into economic analyses, economic-energy balances, and financial sector support.

ORCID ID: $\underline{\text { https://orcid.org/0000-0003-0627-1517 }}$

\section{Joze POLOMSKÝ}

Jozef Polomský is the director of Vector Invest s.r.o., a leader in the processing of eggs, and a manufacturer of dietetic products of egg origin. The company trades in EU markets and exports products to third countries. He is the author and co-author of several patents and utility models in the field of dietetic products. Mr Polomsky also actively works in the field of optimization of internal company processes, improvement of logistics, modernization of the structures of small businesses, their internationalization and internal innovation.

ORCID ID: https://orcid.org/0000-0001-7994-2372

Copyright (C) 2020 by author(s) and VsI Entrepreneurship and Sustainability Center

This work is licensed under the Creative Commons Attribution International License (CC BY).

http://creativecommons.org/licenses/by/4.0/

(c) (7) Open Access 